
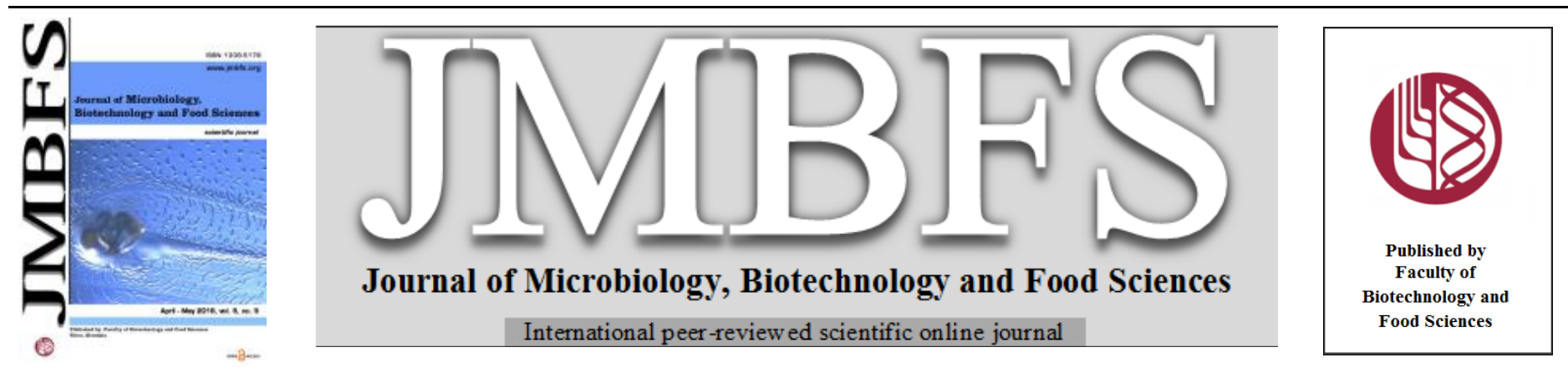

\title{
INVOLVEMENT OF EXTRACELLULAR FUNGAL ENZYMES IN BIOREMEDIATION OF TEXTILE EFFLUENT
}

\section{Rina D. Koyani and Kishore S. Rajput*}

Address(es):

Department of Botany, Faculty of Science, The Maharaja Sayajirao University of Baroda, Vadodara, Gujarat, India-390002.

*Corresponding author: ks.rajput15@yahoo.com

doi: 10.15414/jmbfs.2016.5.5.450-455

\section{ARTICLE INFO}

Received 26. 6. 2014

Revised 21. 4. 2015

Accepted 17. 12. 2015

Published 1. 4. 2016

Regular article

OPEN $\partial_{\text {ACCESS }}$

\begin{abstract}
The plentiful use and reckless discharge of textile effluent to the nature witnessed the rising of water and soil pollution. Biological remediation of these compounds is the most desirable technique to overcome the elevated environmental pollution. Present study evaluates the efficiency of a wild strain of Irpex lacteus in decolourisation and degradation of Reactive yellow FG and Reactive orange 2R. Media supplemented with different carbon/nitrogen sources and inoculum size play important role in enhancing the ability in which dextrose and aspargine boosted the process while inoculum size one-three $(10 \mathrm{~mm}$ diameter) were more significant with solid and liquid decolourisation respectively. The ligninolytic enzyme production under Solid State Fermentation (SSF) was carried out using different lignocellulosic substrates. Among different substrates wheat straw produced highest amount $(560.6 \mathrm{IU} / \mathrm{ml})$ of manganese peroxidase. Optimization of particle size and time of incubation were also assorted to define the efficient enzyme activity; where one mm particle size and $6^{\text {th }}$ day of incubation period were the most felicitous. The influence of physico-chemical factors like $\mathrm{pH}$, temperature, reaction time and metal ions were assessed with respect to enzyme activity. The partial purification of crude enzymes was achieved at different percent saturations, where $40 \%$ saturated fraction yielded maximum $(560.6 \mathrm{IU} / \mathrm{ml}$ ) MnP activity. Molecular weight of the partially purified enzyme was $58.3 \mathrm{kDa}$. The degradation of dyes was confirmed with shift of the dominant peaks found on the FTIR graphs.
\end{abstract}

Keywords: Irpex lacteus, dye decolourisation, dye degradation, solid state fermentation, ligninolytic enzymes

\section{INTRODUCTION}

The huge manufacturing of the dyes due to their massive applications in textile industries has abundantly enhanced the effluent disposal into the environment. As a technological and scientific development in dye technology, they are synthesized as chemically and photolytically more stable and therefore persist in natural environment (Rieger et al., 2002). Consequently leads to worsening of the environment which is inevitably linked with overall quality of life. To mitigate these xenobiotic pollutants, their complete mineralization or transformation into the degradable forms is the only imperative solution on it. Although, many physicochemical techniques are available for efficient mineralization of these dyes, they are very expensive and commercially unattractive. However, biological treatment or biodegradation is an environment friendly and cost-effective alternative to these technologies (Gueu et al., 2007). The Basidiomycetes fungi have the ability of metabolizing lignin. To meet the challenge of lignin degradation, white rot fungi produce one or more of the three principal extracellular enzymes i.e. lignin peroxidises (LiP, EC 1.11.1.14), manganese peroxidase (MnP, EC 1.11.1.13) and laccases (EC 1.10.3.2) (Hatakka, 1994; Asgher et al., 2004). Identification of these enzymes generated one of the credible evolutions for the degradation of aromatic xenobiotics and/or environmental pollutants. Perusal of literature demonstrates the potential of white rot fungi to degrade pollutants by producing extracellular ligninolytic enzymes (Valentin et al., 2007; Wen et al., 2010) and most of them have been focused on dye decolourisation and degradation (Enayatzamira et al., 2009; Champagne $\boldsymbol{e t}$ al., 2010). The initial recognition of the white rot fungi for their decolourizing competency lays the foundation for their application in dye degradation. Therefore, the present study paved the way from dye decolourisation to degradation using the potential of white rot fungus Irpex lacteus.

From extremely diverse range of the textile dyes, most unanimously used reactive dyes (Reactive yellow FG and Reactive orange 2R) have been opted in the present study. The key role of ligninolytic enzymes yielded by Irpex lacteus under solid state fermentation has been emphasized for their ability to degrade the dyes. As the complete purification of enzyme is costly, crude and partially purified enzyme was preferred for their application in enzyme assay and degradation. Influence of different physico-chemical parameters such as inoculum size, effect of $\mathrm{pH}$, temperature, incubation and reaction time, supplementation of carbon/nitrogen sources, and metal ions on enzyme productivity was also investigated. The intermediates formed during degradation of the dyes were analysed by FTIR (Fourier Transform Infrared Spectroscopy). The main objectives of the present study were: i) to evaluate the potential of Irpex lacteus in decolourisation of textile dyes i.e. Reactive yellow FG and Reactive orange $2 \mathrm{R}$; ii) whether the dyes are decolourising or undergoing structural alterations due to enzyme action? and iii) rectification of reactive dyes degradation using ligninolytic enzymes through FTIR.

\section{MATERIALS AND METHODS}

Isolation and screening of the fungi

Thirty five strains of wood rot fungi collected from the different forests of Gujarat State (India) were isolated and plated on optimised malt extract agar (MEA) medium. The purified cultures were subjected to Bavendamm's test (Bavendam, 1928) for the screening of white rot fungi. Among six screened white rot fungi, KSR-70 was considered for the present studies. For molecular identification fungal DNA was extracted as per Möller et al., (1992) and extracted DNA was subjected to Polymerase chain reaction followed by sequencing, BLAST and its submission to the NCBI with Accession No. KJ670229.

\section{Chemicals and dyes}

DMAB (3-dimethyl amino benzoic acid), MBTH (3-methyl-2benzothioazolinone hydrazone hydro chloride), $\mathrm{H}_{2} \mathrm{O}_{2}$ and Manganese Sulphate $\left(\mathrm{MnSO}_{4}\right)$ were procured from National chemicals Ltd., (Vadodara, India). The textile dyes used in the present study were kindly provided by dying, printing and processing houses (Gujarat, India). Chemicals required for the biochemical studies were purchased from Qualigens Fine chemicals (Mumbai, India). All the other chemicals used were commercially available products of analytical grade. 


\section{Solid plate decolourization}

On plate decolourisation of Reactive yellow FG and Reactive orange $2 \mathrm{R}$ was performed on the Malt Extract Agar (MEA)-dye plate containing 2\% malt and $2.5 \%$ agar in the presence of individual dye. The media supplemented with dye concentrations $\left(10,50,100,250\right.$ and $\left.500 \mathrm{mg} \mathrm{L}^{-1}\right)$ were prepared with $25 \mathrm{~mL}$ medium/plate. These petri plates were inoculated centrally with $10 \mathrm{~mm}$ diameter agar disc removed from the actively growing fungi on MEA medium. The decolourisation efficiency was assessed by visual disappearance of dye colours on the plates from $3^{\text {rd }}$ to $15^{\text {th }}$ day of inoculation. Zone of growth and decolourisation were measured at every two days of interval.

\section{Decolourisation in liquid media}

Dye decolourisation experiments were performed in $150 \mathrm{~mL}$ Erlenmeyer flasks containing $25 \mathrm{~mL}$ of $2 \%$ Malt Extract Broth (MEB) supplemented with dyes (10 $\left.\mathrm{mg} \mathrm{L}^{-1}\right)$. Three discs (10 mm diameter) of fungal inoculums taken from active cultures and inoculated in each flask containing sterilized media. Dye decolourisation was investigated by harvesting the inoculated flasks after 3, 5, 7 , 9, 11 and 13 days of incubation. Dye decolourisation was monitore spectrophotometrically by subjecting the filtrate after removing mycelia at the maximum visible wavelength of absorbance $(\lambda \max )$ for individual dyes. All the experiments were performed in triplicates and the average values were considered in calculations. The decolourisation efficiency was expressed as per the following equation.

\section{$\%$ decolourisation $=\underline{\text { Initial } \text { absorbance- }- \text { observed absorbance }} \times 100$ Initial absorbance}

\section{Effect of carbon/nitrogen sources on decolourization}

Different sources of carbon (dextrose, sucrose, fructose, and lactose) and nitrogen (ammonium sulphate, sodium nitrite, asparagine, and urea) at the concentration of $10 \mathrm{~g} \mathrm{~L} \mathrm{~L}^{-1}$ were used as co-substrates to investigate their effects on decolourisation. Influence of these sources on the solid plate decolourisation was checked by inoculating the petridishes (containing growth medium, dyes and carbon/nitrogen sources) with a disc (10mm diameter) of fungal mycelium. The diameters $(\mathrm{cm})$ of the decolourisation and growth zone were determined in two perpendicular directions of the plates at every two days of interval. Un-inoculated plates containing dyes and carbon/nitrogen sources were treated as control. For liquid decolourisation, three plugs of agar discs containing fungal mycelia $(10 \mathrm{~mm}$ diameter) were inoculated in the flask containing MEB (Malt Extract Broth) supplemented with different dyes and carbon/nitrogen sources (1\% concentration). Medium without any of the supplement was used as blank, whereas media with dyes and carbon/nitrogen sources but without inoculums were used as control. Decolourisation efficiency of fungal isolates was measured at the interval of every 3 days using UV-visible spectrophotometer (PerkinElmer, USA) and per cent decolourisation was calculated as per above mentioned equation.

\section{Determination of enzymatic activity by solid state fermentation (SSF)}

\section{Optimisation of different Solid substrates}

Different agro-industrial wastes i.e. wheat straw, rice bran, saw dust, ground nut shells, sugarcane bagasse, and banana pseudo-stems were screened to determine the appropriate substrate for maximum ligninolytic enzyme production using Solid State Fermentation (SSF). Agro-industrial wastes were obtained from local agricultural farms, saw dust was acquired from saw mills situated near Vadodara (Gujarat) while and sugarcane bagasse was procured from the sugarcane industry near Vadodara. Among all individually used agro-industrial waste as a substrate, wheat straw was thriving as the best substrate for enzyme production under SSF. All the substrates were inoculated with pure cultures of the fungal strains and crude extract of these substrates was used for enzyme assay.

\section{Optimisation of particle size and incubation time}

As wheat straw was found as the best substrate for the maximum enzyme production, optimum size of substrate particle was determined by using differen sizes $(<1,1,1.5,2,2.5,3,3.5,4$ and $>4 \mathrm{~mm})$ of wheat straw to get the high efficient enzyme activity. Similarly, time required for the fungal growth and enzyme production is also evaluated. The optimisation of the incubation period was carried out by harvesting the flasks containing solid substrate covered with the fungal mycelia ate every three days till $18^{\text {th }}$ day of inoculation.

\section{Enzyme production and harvesting}

The enzyme production was performed into $250 \mathrm{ml}$ Erlenmeyer flasks containing $5 \mathrm{~g}$ of agro-industrial wastes moistened with $50 \mathrm{~mL}$ distilled water. The sterilized production media was inoculated with five plugs $(10 \mathrm{~mm}$ diameter) of funga inoculum. Flasks were harvested after every three days of inoculation to assess the enzyme activity. Crude extract of extracellular enzymes was prepared by addition of $50 \mathrm{ml}$ phosphate buffer prior to harvesting the flasks. The contents in the flasks were gently beaten and incubated on the rotary shaker for 30 minutes Liquor obtained was filtered by using Whatman filter paper No. 1 and the filtrate was used as a source of crude enzyme.

\section{Enzyme assay}

Crude enzyme obtained by SSF was used for the estimation of extracellular MnP (Manganese Peroxidase), MIP (Manganese Independent Peroxidase) and Laccase activities. These activities were determined by spectro-photometric measurement of DMAB (3-dimethyl amino benzoic acid) and MBTH (3-methyl-2benzothioazolinone hydrazone hydro chloride) as substrates (Vyas et al., 1994). The activities of manganese peroxidises was assayed in $2 \mathrm{~mL}$ of reaction mixture containing $100 \mu \mathrm{L}$ MBTH $(1 \mathrm{mM}), 200 \mu \mathrm{L}$ DMAB $(25 \mathrm{mM}), 10 \mu \mathrm{L} \mathrm{MnSO}_{4}(20$ $\mathrm{mM}), 10 \mu \mathrm{L} \mathrm{H}_{2} \mathrm{O}_{2}(10 \mathrm{mM}), 1000 \mu \mathrm{L}$ buffer $(0.1 \mathrm{M})$, and $100 \mu \mathrm{L}$ enzyme. In case of MIP, the same reaction mixture was used as $\mathrm{MnP}$, except the addition of $\mathrm{MnSO}_{4}$. Conversely, in the reaction mixture of laccase, addition of $\mathrm{MnSO}_{4}$ and $\mathrm{H}_{2} \mathrm{O}_{2}$ were excluded. Oxidation of DMAB and MBTH as chromogen was measured at $590 \mathrm{~nm}$ on Shimadzu UV visible spectrophotometer, where reference blanks contained all components except the assayed enzyme.

The enzyme activity was calculated using the molecular extinction coefficient of $\mathrm{MnP}, \mathrm{MIP}$ and laccase, and expressed in $\mu \mathrm{mol} / \mathrm{min}^{-1}$. One unit (U) of MnP/MIP or laccase was defined as the amount of enzyme necessary to produce one $\mu \mathrm{mol}$ of product per min upon DMAB-MBTH oxidation $(590 \mathrm{~nm})$ of the substrate in the reaction mixture under the assay conditions.

\section{Partial purification and Molecular weight determination of Enzyme}

Crude enzyme was partially purified by ammonium sulphate precipitation method of Dawson et al., (1969) at four different per cent saturations i.e. 20, 40, 60 and 80. From all saturated fractions, maximum activity producing fractions were dialysed with membrane filter having 12000-14000 Da cut off value and collected/stored for further characterization.

The molecular weight of the separated proteins was evaluated by $10 \%$ SDS PAGE (Sodium Dodecyl Sulphate Polyacrylamide Gel Electrophoresis) along with standard protein marker (NEB \# P7708). Gel electrophoresis was performed by using. Electrophoresis of partially purified enzyme as described by Laemmli (1970), using Medox electrophoresis unit (Bioneeds Instruments, India).

\section{Effect of physico-chemical factors on enzyme activity}

Optimisation of enzyme activity with respect to its temperature $\left(10\right.$ to $\left.40^{\circ} \mathrm{C}\right), \mathrm{pH}$ (2.5 to 6.5$)$, incubation time (5 to 45 minutes) and effect of metal ions $(1 \mathrm{mM}$ $\left.0.1 \mathrm{~mL} \mathrm{Mn}^{2+} / \mathrm{Zn}^{2+} / \mathrm{Cu}^{2+} / \mathrm{Ca}^{2+} / \mathrm{Mg}^{2+}\right)$ on enzyme activity was also studied.

Biodegradation analysis by FTIR (Fourier Transform Infrared Spectroscopy)

Degradation of dyes was confirmed by FTIR analysis of treated dyes; where the samples containing $10 \mathrm{~mL}$ dye $\left(10 \mathrm{mg} \mathrm{L}^{-1}\right.$ concentrations) treated with $500 \mu \mathrm{l}$ of partially purified enzyme and then dried at room temperature and processed for FTIR (Shimadzu 8400) analysis by $\mathrm{KBr}$ pellet method at $10^{-4}$ resolution and 30 scan.

\section{RESULTS AND DISCUSSION}

About thirty five strains of wood rot fungi were collected from different forests of Gujarat state. The sterilized fruiting bodies and infected wood samples were processed for the isolation, purification and adaptation of the particular growth media. From all thirty five strains, six were found to be positive with Bavendamm's reaction, showing the complete browning of malt agar medium enriched with $1 \%$ tannic acid (Bavendam, 1928). Among which, Irpex lacteus generating white, cotton-like-fluffy mycelia and radical pattern while growing on malt agar, was selected for the present study.

Irpex lacteus is well characterized for its capacity to decolourise diverse synthetic dyestuffs of main chemical dye groups (Novontny 2004; Choi 2013). On the solid media, it totally decolourised Reactive yellow FG and Reactive orange $2 \mathrm{R}$, with $10 \mathrm{mg} \mathrm{L}^{-1}$ concentration after 11 and 13 days of inoculation respectively (Fig. 1). All the other four dye concentrations tested in the present investigation were also been decolourised easily by the strain (Fig. 2). However, the dye concentration in the growth media plays important role to determine the time required for complete dye decolourisation from the media (Koyani et al., 2013). It is directly proportional to increase in concentration of dye with the decrease in rate of decolourisation. However, the time required for the decolourisation increased gradually with the concentrations from $10,50,100,250$ to $500 \mathrm{mg} \mathrm{L}^{-1}$. Available literature indicates that up to certain concentration of dyes fungal growth occurs but exceeding particular concentration it acts as an inhibitor for growth (Kim et al., 1995; Eichlerova et al., 2006). In the present study, the 
concentration of the dyes up to $100 \mathrm{mg} \mathrm{L}^{-1}$ does not affect the fungal growth, but escalating concentration led to the lessening in growth and decolourisation rate both.

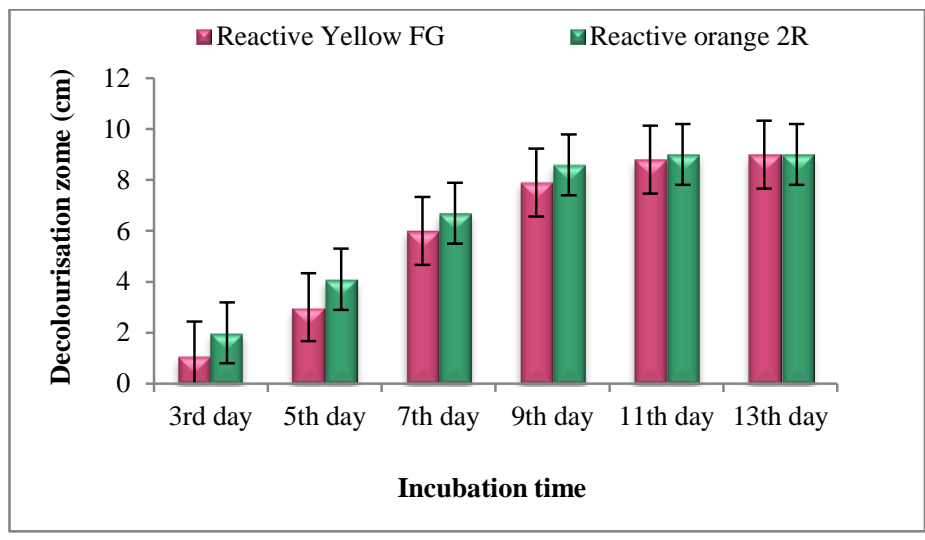

Figure 1 Solid plate decolourisation of two reactive textile dyes i.e. Reactive Yellow FG; Reactive Orange 2R, measured as decolourisation zone $(\mathrm{cm})$ against different incubation time interval (days) using Irpex lacteus.

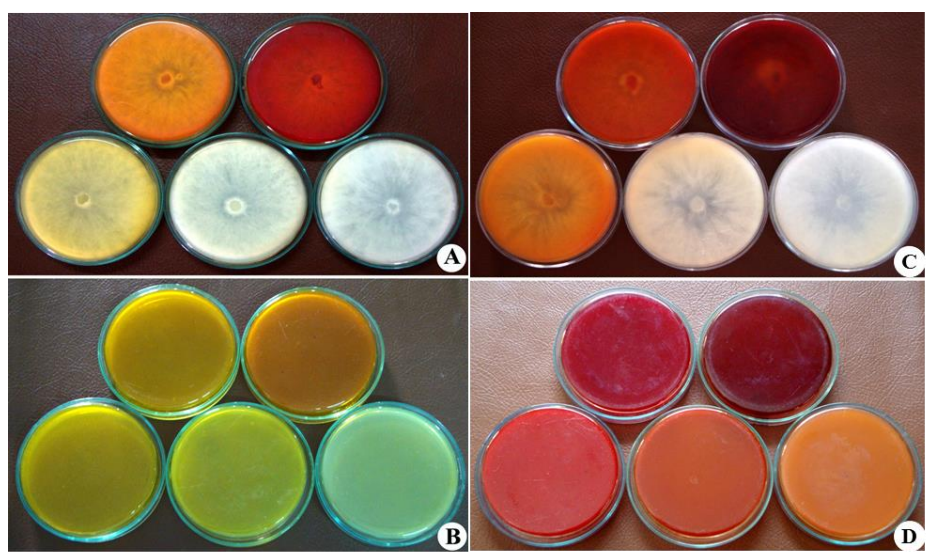

Figure 2 On plate decolourisation of two reactive textile dyes i.e. Reactive Yellow FG (A: Inoculated with Irpex lacteus; B: Blank); Reactive Orange 2R (C: Inoculated with Irpex lacteus ; D: Control) at five different concentrations (10, $50,100,250$ and $500 \mathrm{mg} \mathrm{L}^{-1}$ - from right to left)

The decolourisation of two reactive dyes with different chemical structures by Irpex lacteus was measured as a decrease of visible light absorbance at the wavelength of maximum absorbance $\left(\lambda_{\max }, \mathrm{nm}\right)$ of respective dyes. It bestowed $100 \%$ decolourisation of Reactive yellow FG and Reactive orange $2 \mathrm{R}\left(10 \mathrm{mg} \mathrm{L}^{-1}\right)$ on $11^{\text {th }}$ and $13^{\text {th }}$ day respectively (Fig. 3). I. lacteus decolourise different dyes to various extents depending on their complexity of chemical structure (Novotný $\boldsymbol{e}$ al., 2000; Máximo et al., 2003). Novotný et al., (2000) has also selected $I$. lacteus for its ability to decolourise all the tested dyes with an efficiency of 56 $100 \%$ within 14 days. However, azo dyes are recalcitrant for decolourisation and could be decolourised to a limited extent (Revankar and Lele, 2007). In the present study it was found efficient degraders for both the dyes with concentrations ranging from 10 to $500 \mathrm{mg} \mathrm{L}^{-1}$.

Fungal growth and enzyme production depend upon the growth conditions and the nutrition provided to them (Sanghvi et al., 2010). Any of the additional sources to the medium directly influence decolourisation ability of the fungi. Five different carbon sources (Dextrose, Sucrose, Lactose, Maltose and Fructose) and five nitrogen sources (Ammonium sulphate, Urea, Asparagine, Sodium nitrate and Sodium nitrite) were tested for their effectiveness on solid and in liquid medium to enhance the rate of decolourisation. Among them, dextrose enhanced the rate decolourisation while other carbon sources were relatively less proficient. Glucose can serve as a carbon and energy source, and it could support the dye decolourisation (Sanghvi et al., 2010). However, there is no unanimity about the role of carbon sources in dye decolourisation. Carliell et al., (1995) and Kapdan et al., (2002) also recorded that glucose increases rate of decolourisation while others found no effect of it (Özsoy et al., 2001; Chen et al., 2003) Supplementation of nitrogen in growth media not only influence the ligninolytic enzyme production by several white rot fungi, but also play an important role in the process of dye decolourisation (Moldes et al., 2004). In the present study also, asparagine is reported as an excellent nitrogen source for inducing dye decolourisation while sodium nitrite inhibited the fungal growth.

Different agro-industrial wastes such as saw dust, wheat straw, ground nut shells, rice bran, sugarcane bagasse, and banana pseudo-stems were used as a sole source of carbon without any mineral supplementation in order to determine the most suitable substrate for the production of ligninolytic enzymes. Among all the substrates examined, wheat straw was proved to be unsurpassed lignocellulosic substrate (Fig. 4), for the production of all three ligninolytic enzymes viz. MnP, MIP and Laccase. Wheat straw is one of the best substrate known for the production of enzymes. It is the most widely used substrates among all the other substrates that are employed for this purpose (Valaskova and Baldrian, 2006) Maximum production of ligninolytic enzymes under wheat straw degradation by fungi has already been reported earlier (Zhang et al., 2008; Shrivastav et al. 2011). I. lacteus produced $480.36,440.12$ and $195.19 \mathrm{IU} \mathrm{mL}^{-1}$ as the highest activity for MnP, MIP and laccase, respectively. According to Conesa et al. (2002), a variation in enzyme production by the fungus is a result of its adaptation to different cultural conditions and substrates on which it. In the present study, $\mathrm{MnP}$ is the major protein produced on wheat straw. Vyas et al. (1994) and Hoftrichter et al., (1997) also reported that some white rot fungi show variation in specific enzyme production when grown on wheat straw.

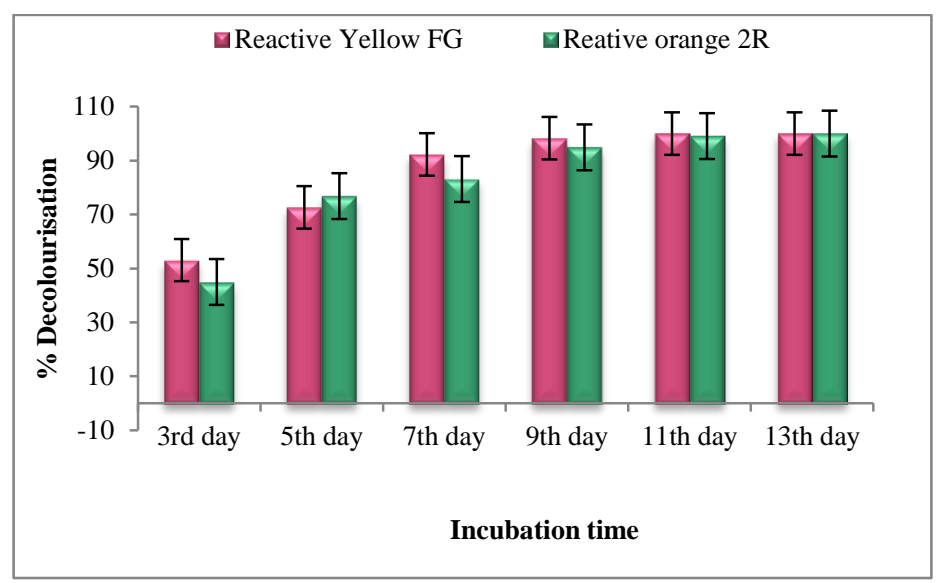

Figure 3 Liquid decolourisation of Reactive Yellow FG and Reactive Orange 2R calculated as \%decolourisation obtained at different time interval (days) using Irpex lacteus.

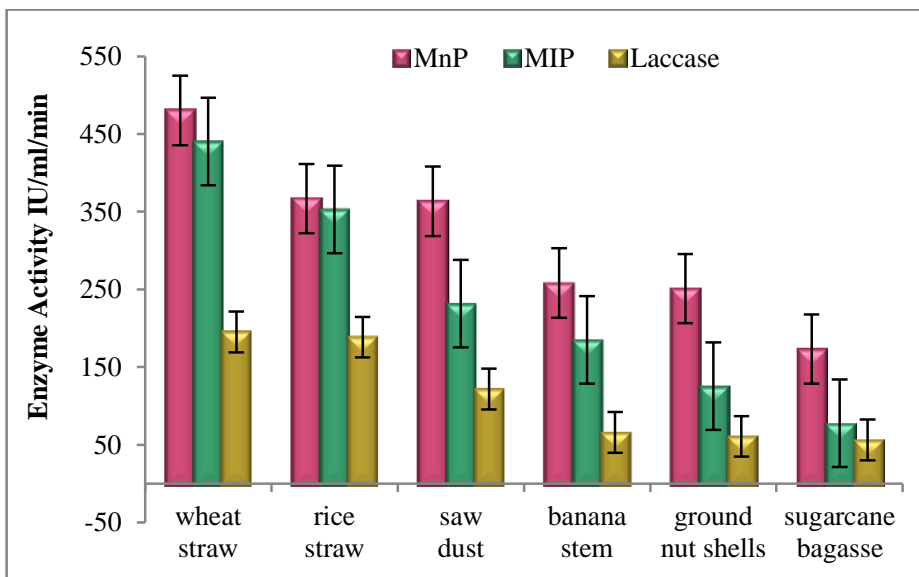

Substrates

Figure 4 Optimization of different solid substrates for the maximum ligninolytic enzyme production by Irpex lacteus

Use of wheat straw as a substrate becomes more exponential when the appropriate particle size of the substrate is used (Sanghvi et al., 2010). I. lacteus when grown on nine different particle sizes $(<1,1,1.5,2,2.5,3,3.5,4$ and $>4 \mathrm{~mm}$ ) of substrates, it produced highest MnP (480.36 IUmL $\left.{ }^{-1}\right)$, MIP (440.12 IU $\mathrm{mL}^{-1}$ ) and laccase (195.19 $\mathrm{IU} \mathrm{mL}^{-1}$ ) with $1 \mathrm{~mm}$ sieve size particles. Production of these enzymes was relatively less at particle size smaller than $1 \mathrm{~mm}$ sieve size. Since the rate of oxygen transfer into the void space affects growth, the substrate should contain particles of suitable sizes to enhance mass transfer (Pandey, 1992). Increase in substrate concentration lead to a decrease in enzyme activity (Gupta et al., 2009). Therefore, declined enzyme production may be associated with increase in viscosity and decrease in porosity of substrate, which consequently affect the available surface area of substrate and oxygen transfer (Gupta et al., 2009; Sanghvi et al., 2010, 2011)

The production of $\mathrm{MnP}$ and laccase by different white rot fungi are more common and predominant (Vyas et al., 1994; Hofrichter et al., 1999). In the present investigation with Irpex lacteus, the optimum ligninolytic enzyme activities of dialyzed partially purified enzyme fraction were $560.6 \mathrm{IU} \mathrm{mL}$ 
(MnP), 534.4 IU mL $\mathrm{mL}^{-1}$ (MIP) and $263.22 \mathrm{IU} \mathrm{mL}^{-1}$ (Laccase). The production profile of MnP was elevated that of MIP and laccase activity. The most common ligninolytic peroxidases produced by majority of white rot basidiomycetes and litter-decomposing fungi are $\mathrm{MnP}$ (Wesenberg et al., 2003). Gupte et al., (2007) and Kasinath, (2002) have reported absence of $\mathrm{MnP}$ activity in I. lacteus whereas Novotný et al., (2001) documented very low level of MnP production by it. We disagree with the earlier reports, since production of manganese peroxidase is a dominant enzyme in Irpex lacteus.

About $90 \%$ of proteins in the crude extract were filtered out in $80 \%$ saturation by ammonium sulphate. The enzyme activities determined from these all the saturated fractions are mentioned in Figure 5. The ammonium sulphate fractions (20-80\% saturation) containing about $90 \%$ of manganese peroxidase was subjected to molecular weight determination. From all 20, 40, 60 and $80 \%$ saturated fractions of crude enzyme; maximum activity $\left(560.6 \mathrm{IU} \mathrm{mL}^{-1}\right)$ of $\mathrm{MnP}$ was recorded with $40 \%$ saturated fraction (Fig. 4). The enhanced enzyme activity and improved purification fold was noticed when compared with the crude extract (Table 1).These dialysed fractions (12000 to $14000 \mathrm{Da}$ ) were subjected to gel electrophoresis where the enzymes appeared as distinct band of $58.3 \mathrm{kDa}$ on SDS-PAGE (Fig. 6). Generally, MnPs of white rot fungi usually have a MW of $45 \mathrm{kDa}$ (Hofrichter, 2002). Shin et al., (2005) isolated MnP from Irpex lacteus with the molecular mass of $53.2 \mathrm{kDa}$, while Baborová et al., (2006) exhibited the $37.5 \mathrm{kDa} \mathrm{MnP}$ from Irpex lacteus, which is quite less compared to our results.

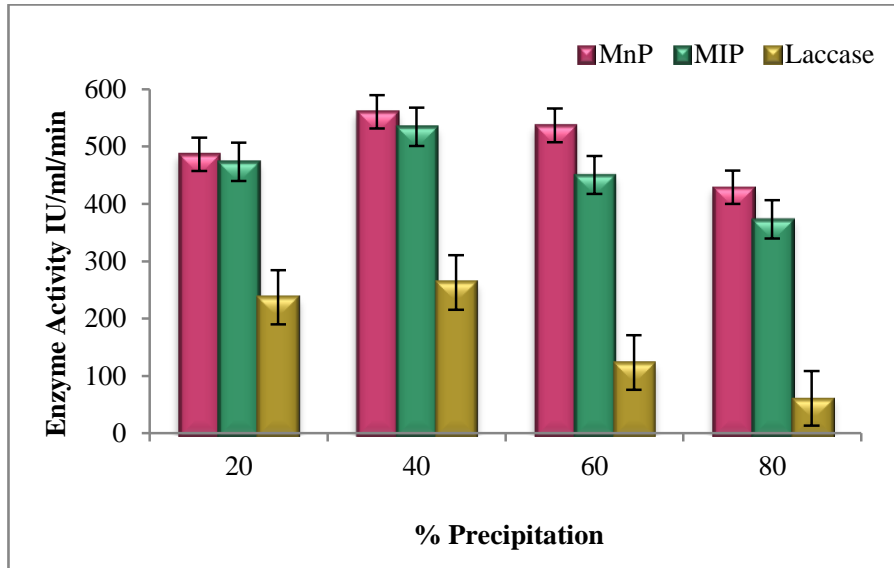

Figure 5 Production profiles of ligninolytic enzymes produced by Irpex lacteus at different ammonium sulphate precipitation saturated fractions $(20 \%, 40 \%$, $60 \%, 80 \%)$

Table 1 Partial purification of Manganese peroxidase

\begin{tabular}{lccc}
\hline & $\begin{array}{c}\text { Enzyme activity } \\
\text { U/ml }\end{array}$ & $\begin{array}{c}\text { Specific activity } \\
\text { U/mg }\end{array}$ & $\begin{array}{c}\text { Purification } \\
\text { fold }\end{array}$ \\
\hline Crude extract & 480.36 & 3.90 & 1.0 \\
$\left(\mathbf{N H}_{4}\right)_{2} \mathbf{S O}_{4}$ & 560.6 & 22.23 & 5.7 \\
$(\mathbf{4 0 \%})$ & & & \\
\hline
\end{tabular}

\section{Lane 1 Lane 2}

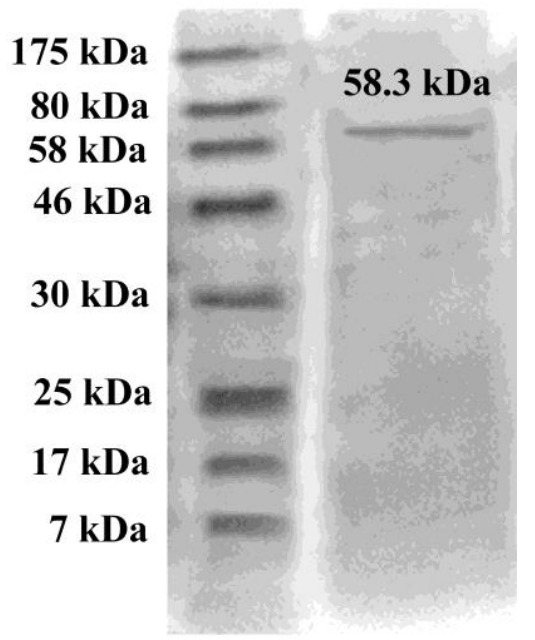

Figure 6 SDS PAGE analysis of partially purified enzyme
Enzymes are highly sensitive to $\mathrm{pH}$ change and it is an important factor that controls the activity of peroxidases (Silva et al., 2008). The range of $\mathrm{pH}$ ( 2.5 to 6.5) ascribed to the enzyme reaction exhibited $\mathrm{pH} 5$ as the most supportive in utmost enzyme production (Fig. 7). This may be attributed to the fact that change in the $\mathrm{pH}$ may alter the three-dimensional structure of the enzymes (Shulter, 2000). Temperature is another crucial factor for determining the fungal growth, which is directly related with the fungal biomass, enzyme production and its activity. This is because during the fermentation there is general increase in the temperature of the fermenting mass due to respiration (Niladevi et al., 2007). Optimisation of the temperature for attaining the excellent enzyme activity was performed within the range of 5 to $45^{\circ} \mathrm{C}$. Available literature suggests that $\mathrm{MnP}$ has an optimal activity between 23 and $40^{\circ} \mathrm{C}$ (Shin et al., 2005), while Baborová et al., (2006) isolated highest titre of $\mathrm{MnP}$ isoenzymes at 50 to $60^{\circ} \mathrm{C}$. Recently, Sklenar et al., (2010) has also shown the reasonable temperature range up to $50^{\circ} \mathrm{C}$ for the production of MnP by Irpex lacteus. However, very far from all these reports, $35^{\circ} \mathrm{C}$ was the flawless match to the optimum enzyme production in the present investigation (Fig. 8).

Baldrian et al., (2005) reported that metal ions play important role in the production of enzyme and concluded that some microelements conferred a significant impact on enzyme activity. Here, five different metal ions i.e. $\mathrm{Mn}^{2+}$ $\mathrm{Zn}^{2+}, \mathrm{Cu}^{2+}, \mathrm{Ca}^{2+}$, and $\mathrm{Mg}^{2+}$ were scanned for their ability to enhance the enzyme activity. It is reported that supplementing cultures with manganese and aromatic compounds can stimulate the $\mathrm{MnP}$ activity by acting as inducers, enhancers or mediators (Hoftrichter et al., 1997). According to Bonnarme and Jeffries (1990) and Scheel et al., (2000), most of the white rot fungi require manganese in the culture medium to increase MnP activity. In contrast, our results exhibited neutral outcome with any of the inducer. The major ligninolytic enzyme produced by I. lacteus, which is not much influenced even after supplementing the inducer such as $\mathrm{Mn}, \mathrm{Cu}$, and $\mathrm{Pb}$ (Baldrian et al., (2005).

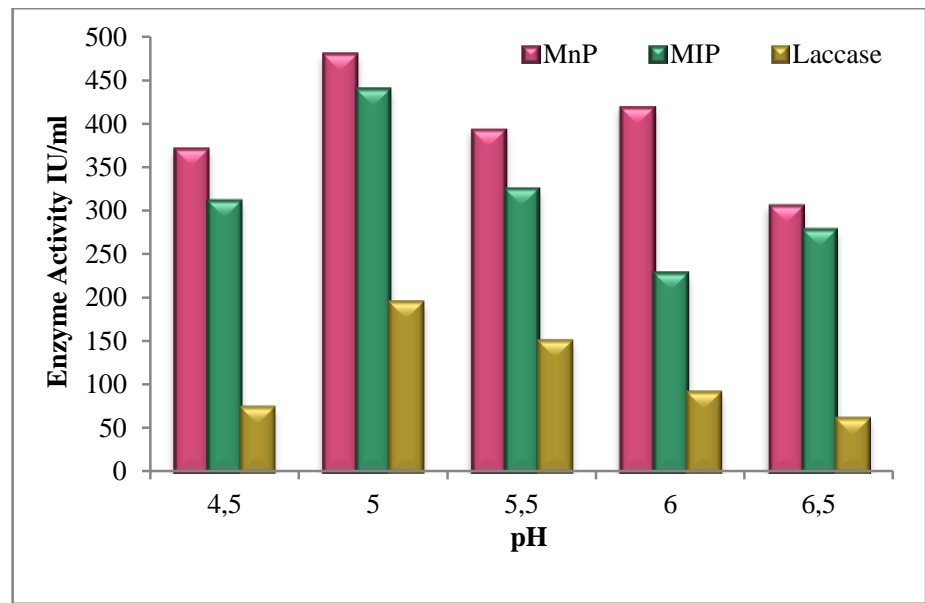

Figure 7 Influence of $\mathrm{pH}$ on ligninolytic enzyme activity produced by Irpex lacteus.

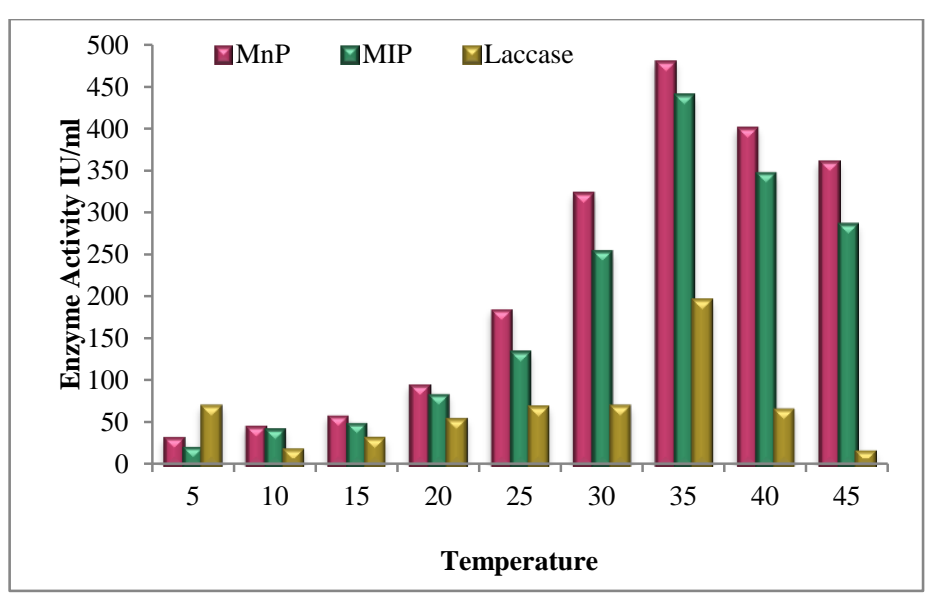

Figure 8 Influence of temperature on ligninolytic enzyme activity produced by Irpex lacteus.

Degradation of various xenobiotic compounds including dyes directly entails the ligninolytic system of white rot fungi. The ability of the white rot fungi to degrade a wide range of recalcitrant dyes has generally been associated with the non-specific nature of their lignin modifying enzymes (Field et al., 1993; 
Goszczynski et al., 1994). For the confirmation of biodegradation of these compounds by ligninolytic enzymes, FTIR analysis was carried out by earlier workers (Kalme et al., 2007; Dhanve et al., 2009; Koyani and Rajput 2014). In the present investigation, the FTIR spectra of both control (untreated) and treated dyes showed stretching of specific peaks in the region 4000 to $500 \mathrm{~cm}^{-1}$. The stretching vibration at $3456 \mathrm{~cm}-1$ represented the $-\mathrm{N}-\mathrm{H}$ stretching which indicates the nature of aromatic amine group present in the parent dye compounds. Azo dyes are aromatic compounds with one or more azo bonds $(-\mathrm{N}=\mathrm{N}-)$ and presence of $-\mathrm{C}-\mathrm{H}$ and $-\mathrm{N}=\mathrm{N}-$ stretching confirmed the azo groups present in the dye, while $-\mathrm{SO}_{2}$ stretch represented the presence of sulpha group in the dye structure. All these stretching confirm the dye structures and when the spectrum of control and treated dyes were compared, changes in the positions of these peaks were observed. Shifting of the peaks to another position from their original location indicates degradation of original dye structure Disappearance of peaks with the vibrations $1545,1345,1230 \mathrm{~cm}^{-1}$ and shifting of the peaks 1697 and $1140 \mathrm{~cm}^{-1}$ representing the C- C stretching can be noticed in case of treated Reactive yellow FG while peaks 3456 and $1385 \mathrm{~cm}^{-1}$ cannot be seen in the treated sample of Reactive orange $2 \mathrm{R}$. Similar changes in the peak of different dyes have already been reported by earlier workers (Field et al., 1993; Goszczynski et al., 1994; Kalme et al., 2007; Dhanve et al., 2009). The FTIR spectral comparison between control dye and samples treated with ligninolytic enzymes of Irpex lacteus showed degradation of both tested dyes (Fig. 9).

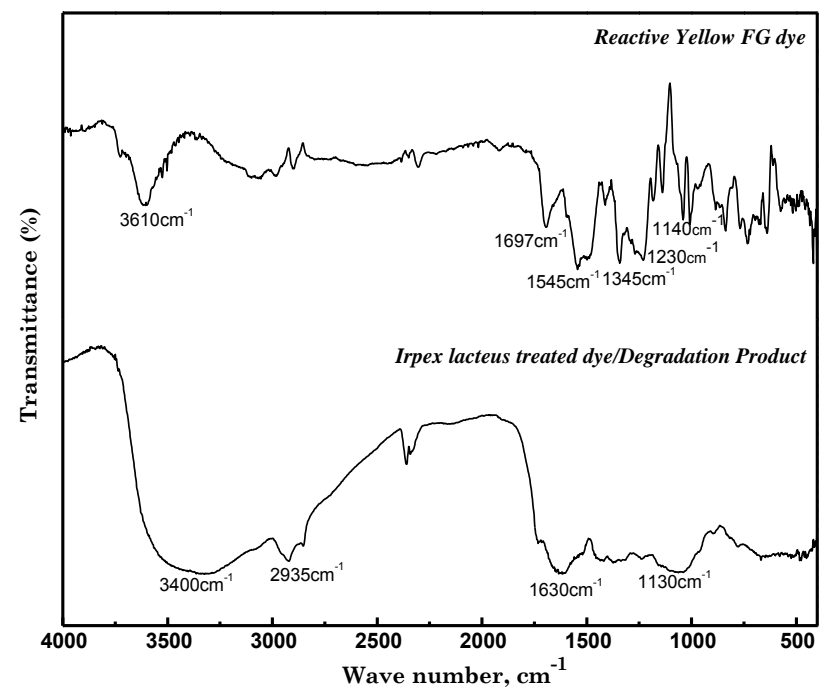

Figure 9A FTIR Spectra of control (upper) and treated dye(lowers)

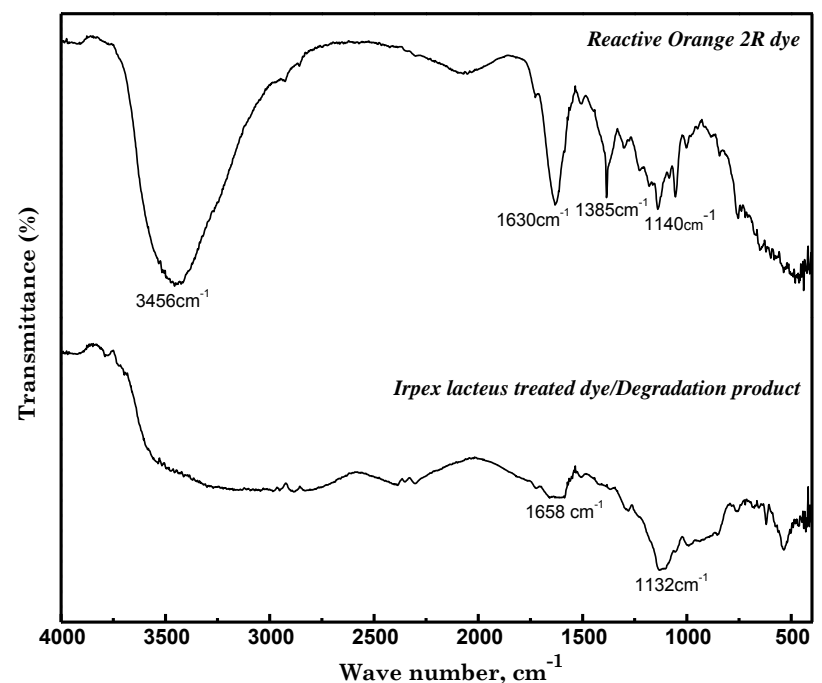

Figure 9B FTIR Spectra of control (upper) and treated dye (lowers)

\section{CONCLUSION}

The white rot fungus Irpex lacteus manifested its decolourization efficiency for reactive textile dyes which are responsible for significant water pollution. The $100 \%$ of decolourization of both reactive dyes is perceived within 13 days. SSF system including the use of agro-industrial wastes is very promising for ligninolytic enzyme production. Production of $\mathrm{MnP}$ was optimal when compared with MIP and laccase. I. lacteus is a potential fungus for the production of ligninolytic enzymes which offer plausible advantage by their use in biodegradation of reactive textile dyes. Therefore, the output of the present study reflects the possibilities of developing the biodegradation technology for textile dyes in an economic way.

Acknowledgement: The authors thank the Council of Scientific and Industria Research (CSIR), Government of India, for the financial support. Thanks are also due to Prof. Ing. Lukáš Hleba (Editor in Chief), and both the anonymous reviewers for their valuable comments on the manuscript.

\section{REFERENCES}

ASGHER, M., BHATTI, H.N., ASHRAF, M., LEGGE, R.L. 2008. Recent developments in biodegradation of industrial pollutants by white rot fungi and their enzyme system. Biodegradation 19, 771-783. http://dx.doi.org/10.1007/s10532-008-9185-3

BABOROVÁ, P., MODER, M., BALDRIAN, P., CAJTHAMLOVÁ, K CAJTHAML, T. 2006. Purification of a new manganese peroxidase of the whiterot fungus Irpexlacteus, and degradation of polycyclic aromatic hydrocarbons by the enzyme. Research Microbiology 157, 248-253. http://dx.doi.org/10.1016/j.resmic.2005.09.001

BALDRIAN, P., VALÁSKOVÁ, V., MERHAUTOVÁ, V., GABRIEL, J. 2005. Degradation of lignocellulose by Pleurotus ostreatus in the presence of copper manganese, lead and zinc. Research Microbiology 156, 670-676.

http://dx.doi.org/10.1016/j.resmic.2005.03.007

BAVENDAM, W. 1928. Uber das Vorkommen den Nachweis von Oxydasen beiholzzer storenden. Pilzenz Pflanzenkrank. Pflanzenschutz 38, 257-276.

BONNARME, P., JEFFRIES, T.W. 1990. Mn (II) regulation of lignin peroxidases and manganese-dependent peroxidases from lignin-degrading white rot fungi. Applied and Environmental Microbiology 56, 210-217.

CARLIELL, C.M., BARCLAY, S.J., NAIDOO, N., BUCKLEY, C.A., MULHOLLAND, D.A., SENIOR, E. 1995. Microbial decolourisation of a reactive azo dye under anaerobic condition. Water Science and Technology 21, 61-69.

CHAMPAGNE, P., NESHEIM, M., RAMSAY, J. 2010. Effect of a non-ionic surfactant, merpol, on dye decolorization of Reactive blue 19 by laccase. Enzyme and Microbial Technology 46, 147-152 http://dx.doi.org/10.1016/j.enzmictec.2009.10.006

CHEN, K.C., WU, J.Y., LIOU, D.J., HWANG, S.C.J. 2003. Decolourization of the textile dyes by newly isolated bacterial strains. Journal of Biotechnology 101, 57-68. http://dx.doi.org/10.1016/S0168-1656(02)00303-6

CONESA, A., PUNT, P.J., VAN DEN HONDEL, C.A. 2002. Fungal peroxidases: molecular aspects and applications. Journal of Biotechnology 93, 143-158. http://dx.doi.org/10.1016/S0168-1656(01)00394-7

DAWSON, R.M.C., ELLIOTT, D.C., JONES, K.M. 1969. Data for Biochemical Research (2nd ed.) Oxford Press, London.

DHANVE, S.R., KALYANI, D.C., PHUGARE, S.S., JADHAV, J.P. 2009 Coordinate action of exiguo bacterial oxidoreductive enzymes in biodegradation of reactive yellow 84A dye. Biodegradation 20, 245-255 http://dx.doi.org/10.1007/s10532-008-9217-z

ENAYATZAMIRA, K., ALIKHANI, H., COUTO, S. 2009. Simultaneous production of laccase and decolouration of the diazo dye Reactive black 5 in a fixed-bed bioreactor. Journal of Hazardous Material 164, 296-300. DOI: 10.1016/j.jhazmat.2008.08.032

EICHLEROVA, I., HOMOLKA, L., NERUD, F. 2006. Synthetic dye decolorization capacity of white rot fungus Dichomitus squalens. Bioresource Technology 97, 153-159.

FIELD, J.A., DE JONG, E., FEIJOO-COSTA, G., DE BONT, J.A.M. 1993 Screening for ligninolytic fungi applicable to the biodegradation of xenobiotics. Trends in Biotechnology 11, 44-99.

GOSZCZYNSKI, S., PASZCZYNSKI, A., PASTI-GRIGSBY, B., CRAWFORD, R.L., CRAWFORD, D.L. 1994. New pathway for degradation of sulphonated azo dyes by microbial peroxidases of Phanerochaete chrysosporium and Streptomyces chromofuscus. Journal of Bacteriology 176, 1339-1347. http://dx.doi.org/0021-9193/94/\$04.00+0

GUEU, S., YAO, B., ADOUBY, K., ADO, G. 2007. Kinetics and thermodynamics study of lead adsorption on to activated carbons from coconut and seed hull of the palm tree. International Journal of Environmental Science and Technology 4, 11-17. http://dx.doi.org/ 10.1007/BF03325956 
GUPTA, V.K., GAUR, R., GAUTAM, N., KUMAR, P., YADAV, I.J., DARMWAL, N.S. 2009. Optimization of xylanase production from Fusarium solani F7. American Journal of Food and Technology 4, 20-29.

GUPTE, A., GUPTE, S., PATEL, H. 2007. Ligninolytic enzyme production under solid state fermentation by white rot fungi. Journal of Science and Industrial Research 66, 611-614

HATAKKA, A. 1994. Ligninolytic enzymes from selected white-rot fungi: production and role in lignin degradation. FEMS Microbiological Reviews 13 , $125-135$.

HOFTRICHTER, M., ZIEGENHAGEN, D., VARES, T., FRIEDRICH, M., JAGER, M.G., FRITSCHE, W., HATAKKA, A. 1997. Oxidative decomposition of malonic acid as basis for the action of manganese peroxidase in the absence of hydrogen peroxide. FEBS Letter 434, 362-366. http://dx.doi.org/10.1016/S0014$\underline{\text { 5793(98)01023-0 }}$

HOFRICHTER, M., SCHEIBNER, K., BUBLITZ, F., SCHNEEGA, I., ZIEGENHAGEN, D., MARTENS, R., FRITSCHE, W. 1999. Depolymerization of straw lignin by manganese peroxidase from Nematolomafrowardii is accompanied by release of carbon dioxide. Holzforschung 53, 161-166.

HOFRICHTER, M. 2002. Review: Lignin conversion by manganese peroxidase (MnP). Enzyme and Microbial Technology 30, 454-466. http://dx.doi.org/10.1016/S0141-0229(01)00528-2

KAPDAN, I.K., KARGI, F. 2002. Biological decolorization of textile dyestuff containing wastewater by Coriolus versicolor in a rotating biological contactor. Enzyme and Microbial Technology 30, 195-199. http://dx.doi.org/10.1016/S0141-0229(01)00468-9

KALME, S.D., GHODAKE, G.S., GOVINDWAR, S.P. 2007. Red HE7B degradation using desulfonation by Pseudomonas desmolyticum NCIM 2112 International Journal of Biodeterioration Biodegradation 60, 327-333. DOI: 10.1016/j.ibiod.2007.05.006

KASINATH, A. 2002. Studies on lignin degradation and bioremediation of textile dyes, Ph.D. Thesis, S.P. University, India.

KIM, S.J., KENICHI, I., MITSUYO, H., MAKOTO, S. 1995. Characteristics of a newly isolated fungus Geotrichum candidum Dec 1, which decolorizes various dyes. Journal of Fermentation and Bioengineering 9, 601-607.

KOYANI, R.D., SANGHVI, G.V., SHARMA, R.K., RAJPUT, K.S. 2013. Contribution of lignin degrading enzymes in decolourisation and degradation of reactive textile dyes. Int. Biodet. Biodegr. 77, 1-9. http://dx.doi.org/10.1016/j.ibiod.2012.10.006

KOYANI, R.D., RAJPUT, K.S. 2014. Application of ligninolytic fungus in decolourisation and degradation of some textile dyes. Progress in Microbiology (in press).

LAEMMLI, U.K. 1970. Cleavage of structural proteins during the assembly of the head of bacteriophage T4. Nature 227, 680-685.

MÁXIMO, C., AMORIM, M.T.P., COSTA-FERREIRA, M. 2003 Biotransformation of industrial reactive azo dyes byGeotrichum sp. CCMI 1019. Enzyme and Microbial Technology 32, 145-151. http://dx.doi.org/10.1016/S0141-0229(02)00281-8

MOLDES, D., LORENZO, M., SANROMÁN, M. A. 2004. Different proportions of laccase isoenzymes produced by submerged cultures of Trametes versicolo grown on lignocellulosic wastes. Biotechnol Letters 26, 327-330.

MÖLLER, E. M., BAHNWEG, G., SANDERMANN, H., GEIGER, H.H. 1992 A simple and efficient protocol for high molecular weight DNA from filamentous fungi, fruit bodies and infected plant tissue. Nucleic Acid Res. 20, 6115-6116

NILADEVI, K.N., SUKUMARAN, R.K., PREMA, P. 2007. Utilization of rice for laccase production by Streptomyces psammoticus in solid-state fermentation. Journal of Industrial Microbiology and Biotechnology 34, 665-674 http://dx.doi.org/10.1007/s10295-007-0239-z

NOVOTNÝ, Č., ERBANOVÁ, P., CAJTHAML, T., ROTHSCHILD, N. DOSORETZ, C., ŠAŠEK, V. 2000. Irpex lacteus, a white rot fungus applicable to water and soil bioremediation. Applied Microbiology and Biotechnology 54, $850-853$

http://dx.doi.org/10.1007/s002530000432

NOVOTNY, C., RAWAL, B., BHATT, M., PATEL, M., SASEK, V. MOLITORIS, H.P. 2001. Capacity of Irpex lacteus and Pleurotus ostreatus for decolorization of chemically different dyes. Journal of Biotechnology 89, 113122. http://dx.doi.org/10.1016/S0168-1656(01)00321-2

ÖZSOY, H.D., UNYAYAR, A., MAZMANC, M.A., DEVECI, T. 2001 Decolourization of a textile dye Remazol Brilliant Blue R by white rot fungi, IV In: Proceedings of the National Environmental Engineering Congress, Mersin, Turkey.

PANDEY, A. 1992. Recent process developments in solid state fermentation Process Biochemistry 27, 109-117. http://dx.doi.org/10.1016/0032 9592(92)80017-W

RIEGER, P.G., MEIER, H.M., GERLE, M., VOGT, U., GROTH, T. KNACKMUSS, H.J. 2002. Xenobiotics in the environment: present and future strategies to obviate the problem of biological persistence. Journal of Biotechnology 94, 101-23. http://dx.doi.org/10.1016/S0168-1656(01)00422-9 REVANKAR, M.S., LELE, S.S. 2007. Synthetic dye decolorization by white rot fungus, Ganoderma sp. WR-1. Bioresource Technology 98, 775-780 http://dx.doi.org/10.1016/j.biortech.2006.03.020
SANGHVI, G.V., KOYANI, R.D., RAJPUT, K. S. 2010. Thermostable xylanase production and partial purification by solid state fermentation using agricultural waste wheat straw. Mycology: Journal of Fungal Biotechnology 1, 106-112. http://dx.doi.org/10.1080/21501203.2010.484029

SANGHVI, G.V., KOYANI, R.D., RAJPUT, K.S. 2011. Isolation, optimization, and partial purification of amylase from Chrysosporium asperatum by submerged fermentation. Journal of Microbiology and Biotechnology 21, 470-476. DOI10.4014/jmb.0910.10014

SCHEEL, T., HOFER, M., LUDWIG, S., HOLKER, U. 2000. Differential expression of manganese peroxidase and laccase in white-rot fungi in the presence of manganese or aromatic compounds. Applied Microbiology and Biotechnology 54, 686-691. http://dx.doi.org/10.1007/s002530000427

SHIN, K.S., KIM, Y.H., LIM, J.S. 2005. Purification and characterization of manganese peroxidase of the white-rot fungus Irpex lacteus. Journal of Microbiology 43, 503-509.

SHRIVASTAV, B., THAKUR, S., PAL, K.Y., GUPTE, A., PUNIYA, A.K., KUHAD, R.C. 2011. White-rot fungal conversion of wheat straw to energy rich cattle feed. Biodegradation 22, 823-831. http://dx.doi.org/10.1007/s10532-0109408-2

SHULTER, M.L., KARGI, F. 2000.Bioprecess engineering basic concept. Prentice Hall of India Pvt. Ltd. New Delhi, India.

SILVA, E.M., MARTINS, S.F., MILAGRES, A.M.F. 2008. Extraction of manganese peroxidase produced by Lentinulaedodes. Bioresource Technology 99, 2471-2475. http://dx.doi.org/10.1016/j.biortech.2007.04.064

SKLENARA, J., NIKU-PAAVOLA, M.L., SANTOSC, S., MANA, P. KRUUSB, K., NOVOTNY, C. 2010. Isolation and characterization of novel pI4 $8 \mathrm{MnP}$ isoenzyme from white-rot fungus Irpex lacteus. Enzyme and Microbial Technology 46, 550-556. http://dx.doi.org/10.1016/jenzmictec.2010.03.01

VALASKOVA, V., BALDRIAN, P., 2006. Estimation of bound and free fractions of lignocellulose-degrading enzymes of wood-rotting fungi Pleurotus ostreatus, Trametes versicolor and Piptoporus betulinus. Research Microbiology 157, 119-124. http://dx.doi.org/10.1016/j.resmic.2005.06.004

VALENTIN, L., LU CHAU, T.A., LO'PEZ, C., FEIJOO, G., MOREIRA, M.T. LEMA, J.M. 2007. Biodegradation of dibenzothiophene, fluoranthene, pyrene and chrysene in a soil slurry reactor by the white-rot fungus Bjerkandera $s p$ BOS5., Process $\quad$ Biochemistry 42, 641-648. http://dx.doi.org/10.1016/j.procbio.2006.11.011

VYAS, B.R.M., BAKOWSKI, S., ŠAŠEK, V., MATUCHA, M. 1994. Degradation of anthracene by selected white rot fungi. FEMS Microbiologica Letters 14, 65-70.

WEN, X., JIA, Y., LI, J. 2010. Enzymatic degradation of tetracycline and oxytetracycline by crude manganese peroxidase prepared from Phanerochaete chrysosporium. Journal of Hazardous Material 177, 924-928. http://dx.doi.org/10.1016/j.jhazmat.2010.01.005

WESENBERG, D., KYRIAKIDES, I., AGATHOS, S.N. 2003. White-rot fungi and their enzymes for the treatment of industrial dye effluents. Biotechnological Advances 22, 161-187. http://dx.doi.org/10.1016/j.biotechadv.2003.08.011

ZHANG, L., DONG, L., LI-JUN, W., TI-PENG, W., ZHANG, L., XIAO, D.C., ZHI-HUAI, M. 2008. Effect of steam explosion on biodegradation of lignin in wheat straw. BioResource Technology 99, 8512-8515. http://dx.doi.org/10.1016/j.biortech.2008.03.028 